\title{
Sustainability management - integrating the multiple dimensions of an interdisciplinary research discipline
}

\author{
Edeltraud Guenther ${ }^{1}$ - Uwe Schneidewind ${ }^{2}$
}

Starting with the publication of Carl von Carlowitz's cutting-edge book "Sylvicultura Oeconomica" in 1713, the first comprehensive treatise on sustainability management, sustainability has a long tradition as a paradigm in Germany. As a responsible manager for the mines in Saxony, von Carlowitz realized that consuming the natural environment by burning wood to produce energy to be used in the mines might be of short-term economic benefit. But in the medium- or even long-term, the ecological sources for creating economic wealth are lost. Even in the short-term there was competition regarding use, i.e. either burning the wood or using it to stabilize the mines. Furthermore, people would lose their jobs, even if there was enough ore, and unemployment caused poverty and social tensions. Therefore, he established rules on how to use the natural environment in a responsible manner. He set the target that companies should only cut as much wood as could regrow in the forest in order to allow a continuous use of the wood:

"... wie eine sothane Conservation und Anbau des Holtzes anzustellen/daß es eine continuirliche beständige und nachhaltende Nutzung gebe..." (von Carlowitz 2000, p. 105).

In this tradition and stimulated by national movements, like the first Environmental Program of the Federal Republic of

Edeltraud Guenther

ema@mailbox.tu-dresden.de

Uwe Schneidewind

uwe.schneidewind@wupperinst.org

1 Technische Universität Dresden, 01062 Dresden, Germany

2 Wuppertal Institute, Döppersberg 19, 42103 Wuppertal, Germany
Germany in 1970, and international developments, like the Brundtland-Report in 1987, the German Academic Association for Business Research (Verband der Hochschullehrer für Betriebswirtschaft e. V.) founded a commission for environmental management in 1990 that later broadened its focus to sustainability management. In 2016, the annual conference of its "Sustainability Management" commission focused on the following mission of the commission:

"It is the purpose of the „Sustainability Management" commission to study companies as experience and design objects in their economic, social, and environmental dimensions. Due to its interdisciplinary nature, sustainability management is a multidimensional construct with diverse facets. The members of the commission aim to integrate differentiated viewpoints in theory and practice, in order to support an objectified understanding and thereby, if possible, jointly supported targets and statements. With this mission in mind, the commission, which understands itself as an interdisciplinary discussion forum, contributes to exploring companies in their relation to the ecological environment as experienced entities. It thereby aims to gain knowledge useful for formulating empirically rich theories in business research and, in turn, derive appropriate design principles and measures. The overarching manner of sustainability research questions in business research sets for the commission the task of 
taking interdisciplinary functions in its relations to other commissions within the association."1

This mission has been developed in an interactive process by all members of the commission, who later agreed upon it formally. Based on this mission of the commission, the focus of the 2016 conference was to analyze how to bring this understanding to life in our work. To this end, we derived the following perspectives from the mission that can lead our work both in research and in practice:

1. Triple bottom line: integrating the three dimensions of sustainability (Elkington 1997) in every single work in business research would be ideal, but as the construct of sustainability is multidimensional (Sharfman and Dean 1991), as each of its subdimension is as well (for the environmental dimension see Trumpp et al. 2015), at least we have to make sure that maximizing one dimension or sub-dimension of sustainability does not cause unintended trade-offs or rebound effects for other sub-dimensions.

Moreover, the extension of the triple bottom line with an intergenerational avenue taking into consideration the time dimension and an intragenerational avenue considering the specific spatial properties in the international context, e.g. water scarcity, is crucial (Lozano 2008). For the spatial dimension, the interaction of local and global perspectives is at stake (Hahn et al. 2015). The German energy transition (Energiewende) is a prominent example for the necessity to integrate the geographical properties. Whereas other areas of business research also focus on the economic and/or social dimension of sustainability or their sub-dimensions such as human resources, the interaction of organizations and the natural environment is specific for sustainability management.

\footnotetext{
1 „Das Anliegen der wissenschaftlichen Kommission Nachhaltigkeitsmanagement ist die Erforschung von Unternehmen als Erfahrungsund Gestaltungsobjekt in ökonomischer, sozialer und ökologischer Dimension. Nachhaltigkeitsmanagement ist aufgrund seines Querschnittcharakters ein hochdimensionales Konstrukt, das sich dem Beobachter vielgestaltig und in zahlreichen Facetten präsentiert. Die Mitglieder der Kommission streben insbesondere nach der Integration differenzierter Sichten in Theorie und Praxis, um über ein objektiviertes Verstehen zu möglichst gemeinsam getragenen Zielsetzungen und Aussagen zu finden. In diesem Selbstverständnis will die Kommission, die sich als ein interdisziplinäres Diskussionsforum sieht, einen Beitrag leisten, Unternehmen in ihren Bezügen zur ökologischen Umwelt als Erfahrungsobjekt zu erforschen, um Erkenntnisse zur Formulierung empirisch gehaltvoller betriebswirtschaftlicher Theorien $\mathrm{zu}$ gewinnen, aus denen wiederum geeignete Gestaltungsprinzipien und -maßnahmen abgeleitet werden können. Die übergreifende Eigenart nachhaltiger Fragestellungen in der Betriebswirtschaftslehre stellt die Kommission zudem vor die Aufgabe, Querschnittsfunktionen in den Beziehungen zu anderen Kommissionen des Verbandes wahrzunehmen." (Verband der Hochschullehrer für Betriebswirtschaft e.V. 2017, 1).
}

2. Interdisciplinary function: Sustainability management can be approached from different disciplines such as engineering, economics, or social science. In addition, it is specific for industries, such as energy, mobility, and the circular economy. Finally, multiple levels, i.e. micro, meso and macro, have to be integrated.

Interestingly enough, the "Sustainability Management" commission is also a very interdisciplinary commission as many of our members are members of another commissions as well, such as production, business ethics, accounting, or marketing. In business practice, many actors of sustainability management have a background in other disciplines, such as engineering, natural science, or psychology.

3. Empirical and conceptual focus: In scholarly publications we can observe a tendency towards empirical work, either quantitative or qualitative with a dominance of quantitative analyses (Bansal and Corley 2012). As empirical work in business research has to rely on ex post data that at most can be extrapolated, an integration of empirical and conceptual work will be necessary to advance sustainability management.

4. Theory and Practice: The interaction of theory and practice (Tucker and Schaltegger 2016) is often a two-way process: In one direction, scholars collect data from companies, either primary data via interviews, questionnaires, documents, or observations or secondary data in terms of archival data from statistics, whether they be internal or external. Thus, data from practice is used for scholarly papers, which will hopefully get published. In the other direction, professors educate students that will become managers and ideally base their decisions on the gained knowledge. An integration of the two worlds should be strived for, thereby fostering transdisciplinary approaches

5. Objectivity: Measures that matter in research are validity (Are you measuring what you want to measure?) (Edwards 2003, Schwab 1980) and reliability (Can your work be reproduced?) and we seek generalizability. We calculate measures like interrater reliability and conduct validity tests, while a review process for scientific articles should foster the distribution of objectified knowledge. By integrating the multiple dimensions and actors in sustainability management, comprehensive assessments can contribute to a reduction in subjectivity.

Against this background papers analyzing research questions from a sustainability perspective, either conceptual or empirical, analyzing the private or public sector, political institutions or society in general are published in this double issue of the UmweltWirtschaftsForum. We invited articles which conceptionally and empirically explore business objects and subjects based on the perspective of sustainabil- 


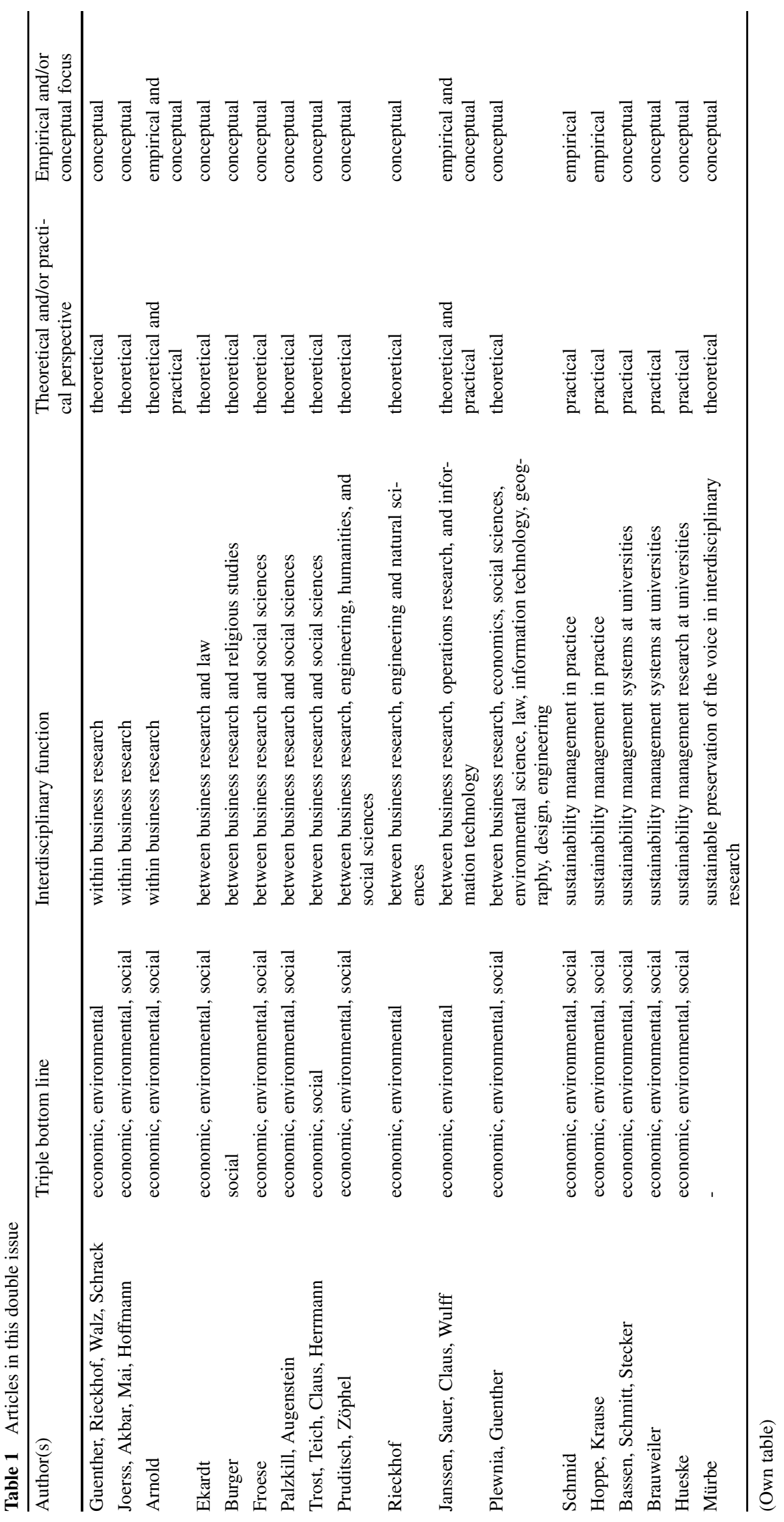


ity, but also build bridges to practice. The focus of research thereby was placed on companies, public institutions, political institutions and the society as a whole. In order to cover the wide spectrum of sustainability management research, we invited articles which cover at least two disciplines, whereby we understand "discipline" both as very narrow as well as very broad.

Table 1 gives an overview of the articles selected for this double issue. It is not surprising to see the focus of the submitted papers in all triple bottom line dimensions. The articles cover interdisciplinary approaches within or between different areas of research, industries, and levels, take empirical and conceptual foci and contribute manifold to theory and practice. This special issue further provides viewpoints from practice (Schmid as well as Hoppe and Krause) and research (Brauweiler, Hueske, and Bassen et al.). To close the double issue, the final article by Mürbe devotes attention to the importance of having a voice in the present society characterized by increasing communication and interdisciplinary needs.

Acknowledgement We thank Dipl.Vw. Ramona Rieckhof for coordinating the articles for the double issue of the UmweltWirtschaftsForum. We further thank the program committee of the fall conference of the commission "Sustainability Management" of the German Academic Association for Business Research (Verband der Hochschullehrer für Betriebswirtschaft e. V.) which took place in fall 2016 at the Technische Universität Dresden, as well as several reviewers for their valuable feedback. Finally, we thank Dr. Jan Endrikat and M. Sc. Teresa Krannich for coordinating the selection of contributions for the fall conference which form the basis for this double issue.

Conflict of interest E. Guenther and U. Schneidewind declare that they have no competing interests.

\section{References}

Bansal P, Corley K (2012) Publishing in AMJ-Part 7: what's different about qualitative research? Acad Manage J 55(3):509-513. doi:10.5465/amj.2012.4003

Edwards JR (2003) Construct validation in organizational behavior research. In: Greenberg J (ed) Organizational behavior: the state of the science, 2nd edn. Erlbaum, Mahwah, pp 327-371

Elkington J (1997) Cannibals with forks: the triple bottom line of 21st century business. Capstone, Oxford

Hahn T, Pinkse J, Preuss L, Figge F (2015) Tensions in corporate sustainability: towards an integrative framework. J Bus Ethics 127(2):297-316

Lozano R (2008) Envisioning sustainability three-dimensionally. J Clean Prod 16:1838-1848
Schwab (1980) Construct validity in organizational behavior. Res Organ Behav 2:3-43

Sharfman MP, Dean JW (1991) Conceptualizing and measuring the organizational environment: a multidimensional approach. J Manage 17(4):681-700

Trumpp C, Endrikat J, Zopf C, Günther E (2015) Definition, conceptualization, and measurement of corporate environmental performance: a critical examination of a multi-dimensional construct. J Bus Ethics 126:185-204

Tucker BP, Schaltegger S (2016) Comparing the research-practice gap in management accounting. Account Auditing Account $\mathbf{J}$ 29(3):362-400

Verband der Hochschullehrer für Betriebswirtschaft e.V. (2017) Selbstverständnis/Historie. http://nama.vhbonline.org/selbstverstaend nis/. Accessed 22. Mai 2017

Von Carlowitz HC (2000) Sylvicultura oeconomica - oder Anweisung zur wilden Baumzucht. Nachdruck der Ausgabe Leipzig 1713. TU Bergakademie, Freiberg i.S (Veröffentlichungen der Bibliothek „Georgius Agricola“ an der Bergakademie Freiberg 135)

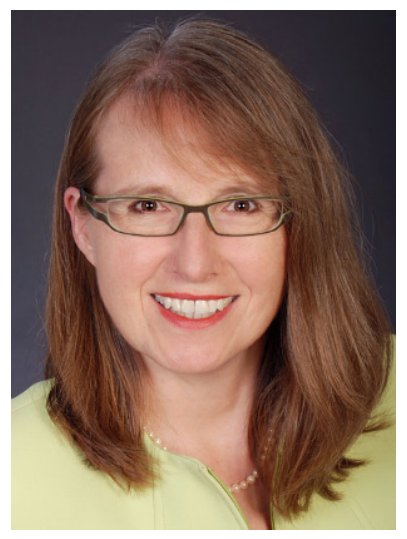

Edeltraud Guenther

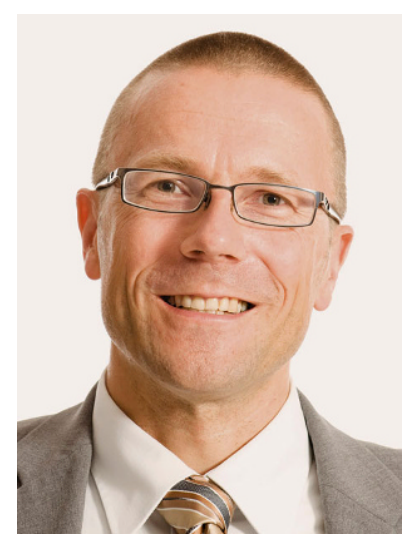

Uwe Schneidewind 